\title{
Performance of blackgram (Phaseolus mungo L.) cultivars as influenced by row spacings and molybdenum
}

\author{
Ravi Kumar \\ Department of Agronomy, College of Agriculture Indira Gandhi Krishi Vishwa Vidyalaya, \\ Raipur (Chhattisgarh), India
}

\section{G. S. Tomar}

Department of Agronomy, College of Agriculture Indira Gandhi Krishi Vishwa Vidyalaya, Raipur (Chhattisgarh), India

Narendra Kumawat*

AICRP on Maize, Zonal Agricultural Research Station, Jhabua - 457661 (M.P.), India Jagdeesh Morya

Krishi Vigyan Kendra, Jhabua - 457661 (M.P.), India

*Corresponding author. E-mail: kumawatandy@gmail.com

\section{ABSTRACT}

A field trial was conducted to assess the performance of blackgram cultivars to row spacings and molybdenum doses at the Instructional-cum-Research Farm, Indira Gandhi Krishi Vishwavidyalya, Raipur (Chhattisgarh), under rainfed conditions during kharif season of 2011. The treatments comprised of three varieties viz., Indra urd-1, RU-03-16 and RU-03-52; two row spacings viz., $30 \times 10 \mathrm{~cm}$ and $45 \times 10 \mathrm{~cm}$ and three treatments of molybdenum viz., control, $4 \mathrm{~g} / \mathrm{kg}$ seed and $4 \mathrm{~g} / \mathrm{kg}$ seed + two spray of urea @ $2 \%$. The experiment was laid out in factorial randomized block design (FRBD) with three replications. Results revealed that all the growth and yield attibutes such as number of branches/plant, number of leaves/plant, seeds/plant, seed yield $(781 \mathrm{~kg} / \mathrm{ha})$, biological yield $(2736 \mathrm{~kg} / \mathrm{ha})$ and harvest index $(29.71 \%)$ noticed significantly higher under cultivar Indra urd-1. Similarly, maximum production efficiency $(9.52 \mathrm{~kg} / \mathrm{ha} /$ day $)$, economic efficiency (Rs. 218.82/ha/day) and gross returns (Rs. 32,335/ha) were also recorded in Indra urd-1 as compared to rest of the cultivars. Further results showed that all the growth and yield attributes viz., number of branches/plant, number of leaves/plant, seeds/plant, seed yield $(778 \mathrm{~kg} / \mathrm{ha})$, biological yield $(2653 \mathrm{~kg} / \mathrm{ha})$ and harvest index $(29.10 \%)$ recorded significantly higher in row spacing of $30 \times 10 \mathrm{~cm}$ as compared to $45 \times 10 \mathrm{~cm}$. Maximum production efficiency $(9.49 \mathrm{~kg} / \mathrm{ha} /$ day), economic efficiency (Rs. $216.44 / \mathrm{ha} /$ day) and gross returns (Rs. 32,107/ha) were also recorded in $30 \times 10 \mathrm{~cm}$. Application of molybdenum @ $4 \mathrm{~g} / \mathrm{kg}$ seed along with 2\% urea spray twice gave highest seed yield $(810 \mathrm{~kg} /$ ha), biological yield $(2698 \mathrm{~kg} / \mathrm{ha})$ and harvest index $(29.25 \%)$ over control and seed treatment with molybdenum @ $4 \mathrm{~g} / \mathrm{kg}$. Similarly, application of molybdenum + 2\% urea spray twice gave maximum production efficiency $(9.88 \mathrm{~kg} / \mathrm{ha} /$ day $)$, economic efficiency (Rs. 226.49/ha/day) and gross returns (Rs. 33,293/ha).

Keywords: Blackgram, Cultivars, Economic efficiency, Molybdenum, Row spacings, Yields

\section{INTRODUCTION}

Pulses have occupied immense significance in recent years as an important component of Indian economy. Pulses are seeds of leguminous plants and belong to the family Fabaceae. Pulses are rich source of protein and thus form an important part of vegetarian diet supplying the major portion of the protein requirements to human nourishment. About 88 per cent of protein consumed in India is of vegetable origin. Pulses have $2-6 \%$ fats and can meet the essential fatty acids (Kumar et al. 2018 and Mahilane and Singh, 2018). Blackgram is a widely grown grain legume and as-

\section{Article Info}

DOI:10.31018/jans.v10i2.1706

Received: March 2, 2018

Revised: April 18, 2018

Accepted: May 13, 2018

\section{How to Cite}

Kumar, R. et al. (2018).

Performance of blackgram (Phaseolus mungo L.) cultivars as influenced by row spacings and molybdenum. Journal of Applied and Natural Science, 10 (2): 753 - 758 
sary for interception of sunlight to each stratum of plant leaves which enhances the rate of phosynthesis consequently dry matter production (Joshi and Rahevar, 2015). Row planting facilitates easy intercultural operations resulting in higher yields. Row planting with appropriate planting density can help ensure optimum plant population/unit area thereby increasing the yield.

Micronutrients play an important role in increasing legume yield through their effect on the plant itself, nitrogen fixing symbiotic process and effective use of major and secondary nutrients. Among micronutrients, cobalt and molybdenum are essential for the growth of Rhizobium and nitrogen fixation (Singh et al., 2017). Molybdenum is very low in many soils. Application of molybdenum significantly increased the vegetative growth, nodule numbers, grain protein content and yield of blackgram as compared to control (Kumar et al., 2010). The essential role is played by trace elements in nutrition and metabolism of plant. Molybdenum, one of the important member of this group is of special significance due to its contribution in activation of several enzyme systems and physiological activities encountered

inside the plant body. Molybdenum is a constituent part of the enzyme nitrate reductase concerned with the reduction of nitrate to nitrite in both micro organism and higher plants. It is also known to be specific inhibitor for acid phosphatase. Deficiency of molybdenum has also been shown to decrease the concentration of sugars, particularly reducing sugars, suggesting an involvement of molybdenum in carbohydrate metabolism (Malik et al., 2015). The reasons for low yield are manifold: some are plant geometry, varietals and some are agronomic management practices. Keeping these facts, a field experiment was conducted to investigate the performance of blackgram (Phaseolus mungo L.) as affected by row spacings, cultivars and seed treatment with molybdenum.

\section{MATERIALS AND METHODS}

A field experiment was planned to assess the effect of row spacings, cultivars and seed treatment with molybdenum on growth, yields and profitability of blackgram conducted at the Instructionalcum-Research Farm, Indira Gandhi Krishi Vishwavidyalya, Raipur (Chhattisgarh), under rainfed conditions during kharif season of 2011. The experiment was laid out in factorial randomized block design with three replications. The treatments comprised of three varieties viz., $\mathrm{V}_{1}=$ Indra urd-1, $\mathrm{V}_{2}=\mathrm{RU}-03-16$ and $\mathrm{V}_{3}=\mathrm{RU}-03-52$; two plant density viz., $\mathrm{P}_{1}=30 \times 10 \mathrm{~cm}$ and $\mathrm{P}_{2}=45 \times 10 \mathrm{~cm}$ and three treatments of molybdenum viz., $S_{1}=$ control, $S_{2}=4 \mathrm{~g} / \mathrm{kg}$ seed and $S_{3}=4 \mathrm{~g} / \mathrm{kg}$ seed along with two spray of 2 urea @ $2 \%$. The soil of the experiment field was black clay soil (sand
52.46 , silt 22.28 and clay $25.26 \%$ ) in texture, neutral in soil reaction $(\mathrm{pH} 7.05)$, low in organic carbon $(0.43 \%)$, available $\mathrm{N}(193.2 \mathrm{~kg} / \mathrm{ha})$, available $\mathrm{P}(9.87 \mathrm{~kg} / \mathrm{ha})$ and high in available $\mathrm{K}(310.2 \mathrm{~kg} /$ ha). Seeds of blackgram were sown on $07^{\text {th }}$ July 2011 with two spacing of $30 \times 10 \mathrm{~cm}$ and $45 \times 10$ $\mathrm{cm}$. Crop was sown on well prepared seedbed in lines with single row hand drill. Recommended dose of fertilizers (NPK) was applied as basal dose before sowing of crop. Seed treatment with molybdenum @ $4 \mathrm{~g} / \mathrm{kg}$ done as per treatments. Foliar spray of $2 \%$ DAS was given twice at flower initiation and 15 days later as per treatments. For reduce weed infestation, one hand weeding was done at 25 days after sowing (DAS) and second on 45 DAS. All other cultural practices such as hoeing, irrigation, insect- pest control were kept normal for all the treatments. In each treatment plot and replications, randomly five plants were selected and their respective branches/plant, leaves/plant and seeds/plant was recorded. After threshing and winnowing the weight of seeds for each net plot area was recorded in $\mathrm{kg} /$ plot and then converted to $\mathrm{kg} / \mathrm{ha}$. Harvest index was calculated as per suggested formula by Kumar et al. (2014). Production efficiency and economic efficiency was calculated as following formula suggested by Kumawat et al. (2015). The data collected on various parameters was analyzed statistically by using Fisher's analysis of variances techniques and differences among treatment means were compared by using LSD at $5 \%$ probability level (Ranganathan, 1990).

\section{RESULTS AND DISCUSSION}

Effect of cultivars on yields and economics: The results revealed that growth characters (number of branches/plant and number of leaves/ plant), yield attributes (seeds/plant), seed yield, biological yield and economics were significantly influenced due to cultivars (Table 1). Among the different cultivars, significantly higher values of number of branches/plant (3.07, 4.92 and 5.38 at 40, 60 DAS and harvest stage, respectively) was noted by the cultivar Indira Urd-1 which was superior to RU-03-16 and RU-03-52. Similarly, cultivar Indira Urd-1 produced maximum number of leaves/plant (8.65, 14.79 and 13.67 at 40, 60 DAS and harvest stage, respectively) which was shown superiority over rest of cultivars. Significantly higher number of seeds/plant (141.54) was recorded by Indira Urd-1 cultivar as compared to RU-03-52 (125.29) and RU-03-16 (117.02). This might be due to genetically variability of cultivar. The results are in line with those reported by Kabir and Sarkar (2008), Panotra et al. (2016) and Kumar et al. (2018).

Among the various cultivars, Indira Urd-1 produced significantly highest seed yield $(781 \mathrm{~kg} / \mathrm{ha})$ and biological yield (2736 kg/ha) as compared to 
Kumar R. et al. / J. Appl. \& Nat. Sci. 10 (2): 753 - 758 (2018)

Table 1. Branches/plant, leaves/plant and seeds/plant of blackgram as influenced by cultivars, row spacings and seed treatment with molybdenum.

\begin{tabular}{|c|c|c|c|c|c|c|c|}
\hline \multirow[t]{2}{*}{ Treatments } & \multicolumn{3}{|c|}{ Number of branches/plant } & \multicolumn{3}{|c|}{ Number of leaves /plant } & \multirow{2}{*}{$\begin{array}{l}\text { Seeds/ } \\
\text { plant }\end{array}$} \\
\hline & 40 DAS & 60 DAS & At harvest & 40 DAS & 60 DAS & At harvest & \\
\hline \multicolumn{8}{|l|}{ Cultivars } \\
\hline Indira Urd-1 & 3.07 & 4.92 & 5.38 & 8.65 & 14.79 & 17.86 & 141.54 \\
\hline RU-03-16 & 2.65 & 4.11 & 4.87 & 8.17 & 13.65 & 16.08 & 117.02 \\
\hline RU-03-52 & 2.87 & 4.61 & 4.95 & 7.97 & 12.11 & 15.63 & 125.29 \\
\hline SEm \pm & 0.01 & 0.02 & 0.02 & 0.02 & 0.05 & 0.05 & 1.11 \\
\hline$C D(P=0.05)$ & NS & 0.07 & 0.07 & NS & 0.16 & 0.15 & 3.50 \\
\hline \multicolumn{8}{|l|}{ Row spacings } \\
\hline $30 \times 10 \mathrm{~cm}$ & 2.68 & 4.14 & 4.48 & 8.13 & 13.01 & 16.16 & 127.00 \\
\hline $45 \times 10 \mathrm{~cm}$ & 3.05 & 4.95 & 5.65 & 8.40 & 14.05 & 16.89 & 134.00 \\
\hline SEm \pm & 0.01 & 0.02 & 0.04 & 0.01 & 0.03 & 0.03 & 0.74 \\
\hline$C D(P=0.05)$ & NS & 0.06 & 0.12 & NS & 0.10 & 0.10 & 2.33 \\
\hline \multicolumn{8}{|l|}{ Seed treatments } \\
\hline Control & 2.46 & 3.95 & 4.44 & 7.99 & 12.53 & 15.40 & 106.23 \\
\hline Mo@4g/kg seed & 2.84 & 4.63 & 5.11 & 8.37 & 13.8 & 16.6 & 122.55 \\
\hline $\begin{array}{l}\text { Seed treatment with Mo } \\
+2 \% \text { urea spray twice }\end{array}$ & 3.30 & 5.05 & 5.65 & 8.43 & 14.25 & 17.58 & 153.30 \\
\hline SEm \pm & 0.03 & 0.06 & 0.05 & 0.06 & 0.10 & 0.10 & 5.78 \\
\hline$C D(P=0.05)$ & NS & 0.20 & 0.16 & NS & 0.30 & 0.30 & 16.86 \\
\hline
\end{tabular}

Table 2. Yields and economics of blackgram as influenced by cultivars, row spacings and seed treatments with molybdenum.

\begin{tabular}{|c|c|c|c|c|c|c|c|}
\hline Treatments & $\begin{array}{l}\text { Grain } \\
\text { yield } \\
\text { (kg/ha) }\end{array}$ & $\begin{array}{l}\text { Biological } \\
\text { yield } \\
\text { (kg/ha) }\end{array}$ & $\begin{array}{l}\text { Harvest } \\
\text { Index (\%) }\end{array}$ & $\begin{array}{l}\text { Production } \\
\text { efficiency } \\
\text { (kg/ha/day) }\end{array}$ & $\begin{array}{l}\text { Cost } \\
\text { incurred } \\
\text { (Rs./ha) }\end{array}$ & $\begin{array}{l}\text { Gross } \\
\text { returns } \\
\text { (Rs./ha) }\end{array}$ & $\begin{array}{l}\text { Economic } \\
\text { efficiency } \\
\text { (Rs./ha/day) }\end{array}$ \\
\hline \multicolumn{8}{|l|}{ Cultivars } \\
\hline Indira Urd-1 & 781 & 2736 & 29.71 & 9.52 & 14392 & 32335 & 218.82 \\
\hline RU-03-16 & 718 & 2491 & 27.50 & 8.76 & 14202 & 29566 & 187.38 \\
\hline RU-03-52 & 766 & 2635 & 28.68 & 9.34 & 14297 & 31519 & 210.04 \\
\hline SEm \pm & 1.0 & 2.0 & 0.05 & 0.01 & - & 44 & 0.54 \\
\hline$C D(P=0.05)$ & 4.0 & 6.0 & 0.17 & 0.05 & - & 139 & 1.70 \\
\hline \multicolumn{8}{|l|}{ Row spacings } \\
\hline $30 \times 10 \mathrm{~cm}$ & 778 & 2653 & 29.10 & 9.49 & 14360 & 32107 & 216.44 \\
\hline $45 \times 10 \mathrm{~cm}$ & 732 & 2589 & 28.18 & 8.93 & 14233 & 30173 & 194.39 \\
\hline SEm \pm & 1.0 & 1.0 & 0.38 & 0.01 & - & 29 & 0.35 \\
\hline $\begin{array}{l}C D(P=0.05) \\
\text { Seed treatments }\end{array}$ & 2.0 & 3.0 & 0.12 & 0.02 & 0 & 93 & 1.13 \\
\hline Control & 703 & 2547 & 28.02 & 8.57 & 13818 & 29089 & 186.23 \\
\hline $\begin{array}{l}\text { Mo @ } 4 \mathrm{~g} / \mathrm{kg} \text { seed } \\
\text { Seed treatment Mo + }\end{array}$ & 751 & 2617 & 28.62 & 9.16 & 14350 & 31038 & 203.51 \\
\hline $2 \%$ urea spray twice & 810 & 2698 & 29.25 & 9.88 & 14722 & 33293 & 226.49 \\
\hline SEm \pm & 7.0 & 8.0 & 0.11 & 0.09 & - & 273 & 3.35 \\
\hline$C D(P=0.05)$ & 20.0 & 22.0 & 0.33 & 0.24 & - & 797 & 10.45 \\
\hline
\end{tabular}

RU-03-52 and RU-03-16 (Table 2). While lowest seed yield was recorded in RU-03-16 (718 kg/ha). The increase in grain yield and biological yield was 8.77 and 9.70 per cent by the Indira Urd-1 as compared to RU-03-16. Similar trend was also followed in harvest index. Significantly higher harvest index $(29.71 \%)$ was observed in cultivar Indira Urd-1 as compared to RU-03-16. This could be ascribed due to variation occurred due to the contribution of different yield traits. Harvest index is an important physiological character that reflects dry matter partitioning of a given genotype to the economic part. Higher harvest index results higher crop yield probably due to more partitioning of dry matter to reproductive sink. Similar results have been reported by Singh et al. (2011) in mungbean, Panotra et al. (2016) in blackgram and Kumar et al. (2018) in blackgram.

Further date presented in table 2 showed that maximum cost of cultivation Rs. 14,392/ ha and gross returns of Rs. 32,335/ha was observed in Indira Urd-1 followed by RU-03-52 and RU-03-16 (Table 2). The better yield attributes and yields produced by Indira Urd-1 which might be responsible for higher the economics of blackgram. The maximum production efficiency $(9.52 \mathrm{~kg} / \mathrm{ha} / \mathrm{day})$ and economic efficiency (Rs. 218.82/ha/day) was also recorded with Indira Urd-1 cultivar which was proven superiority among the cultivars. Similar findings were also made by Joshi Rahevar (2015) 
Kumar R. et al. / J. Appl. \& Nat. Sci. 10 (2): 753 - 758 (2018)

Table 3. Interaction effects of cultivars, row spacings and seed treatments with molybdenum on grain yield (kg/ha)

\begin{tabular}{lllllll}
\hline Treatments & $\mathbf{P}_{\mathbf{1}}$ & $\mathbf{P}_{\mathbf{2}}$ & Treatments & $\mathbf{V}_{\mathbf{1}}$ & $\mathbf{V}_{\mathbf{2}}$ & $\mathbf{V}_{\mathbf{3}}$ \\
\hline $\mathrm{V}_{\mathbf{1}}$ & 814.16 & 747.13 & $\mathrm{~S}_{1}$ & 718.43 & 682.01 & 708.96 \\
$\mathrm{~V}_{2}$ & 729.77 & 705.75 & $\mathrm{~S}_{2}$ & 776.41 & 720.76 & 757.18 \\
$\mathrm{~V}_{3}$ & 789.02 & 742.9 & $\mathrm{~S}_{3}$ & 847.09 & 750.51 & 831.73 \\
Interactions & To compare means of & & $\mathrm{SEm} \pm$ & & $\mathrm{CD}(\mathrm{P}=0.05)$ \\
$\mathrm{VxP}$ & \multicolumn{2}{r}{} & & 6.84 & & 21.56 \\
$\mathrm{VxS}$ & 2 S levels at same V & & 16.44 & & 47.99 \\
& 2 V levels at same S & & 14.20 & & 42.62 \\
\hline
\end{tabular}

in Indian bean and Kumar et al. (2018) in blackgram.

Effect of row spacings on yield and economics: Row spacings significantly influences on growth characters viz., number of branches/plant and number of leaves/plant, yield attributes viz., seeds/plant, seed yield, biological yield, harvest index, gross returns, production efficiency and economic efficiency of blackgram (Tables 1). Significantly the maximum number of branches/plant (3.05, 4.75 and 5.65 at 40, 60 DAS and harvest stage, respectively) was recorded at $45 \times 10 \mathrm{~cm}$ plant spacing as compared to $30 \times 10$ plant spacing. Further data revealed that maximum number of leaves/plant (8.40, 14.05 and 16.89 at 40, 60 DAS and harvest stage, respectively) was noted under density $45 \times 10 \mathrm{~cm}$ which was significantly superior over $30 \times 10 \mathrm{~cm}$. Due to wider spacing might attributed to crop growth and development was suppressed due to intra-specific competition particularly for moisture, light and nutrients which might be resulted in less number of branches and thereby reduced dry matter accumulation plant. These results are in agreement with that reported by Singh et al. (2011) in mungbean. Similarly, significantly higher number of seeds/plant (134.0) was recorded under wider row spacing of $45 \times 10$ $\mathrm{cm}$ as compared to $30 \times 10 \mathrm{~cm}$. This was probably due to more space per plant ultimately enhanced availability of nutrients, moisture and light consequently better development of yield attributes. These results are in contradiction with those obtained by Satyamoorthi et al. (2008) in greengram Panotra et al. (2016) in blackgram.

The highest seed yield of $778 \mathrm{~kg} / \mathrm{ha}$ and biological yield of $2653 \mathrm{~kg} / \mathrm{ha}$ was obtained with $30 \times 10 \mathrm{~cm}$ row spacing which was significantly superior over $45 \times 10 \mathrm{~cm}$ plant spacing (Table 2). Similarly, significantly higher harvest index was observed in spacing of $30 \times 10$. The increase in seed yield and biological yield was sown $30 \times 10 \mathrm{~cm}$ plant spacing was 6.88 and 2.47 per cent, respectively as compared to $45 \times 10 \mathrm{~cm}$. This might be due to better expression of growth characters and yield attributes as discussed earlier may also be the possible reasons for the production of higher yields. These results are in agreement with that reported by Kabir and Sarkar (2008) in mungbean, Kumar et al. (2013) in blackgram and Pa- notra et al. (2016) in blackgram.

Higher gross returns of Rs. 32,107 was fetched in $30 \times 10 \mathrm{~cm}$ spacing and lowest in $45 \times 10 \mathrm{~cm}$ (Rs.30173/ha). The highest production efficiency (9.49 kg/ha/day) and economic efficiency (Rs. $244.16 /$ ha/day) was recorded with $30 \times 10 \mathrm{~cm}$ row spacing followed by in $45 \times 10 \mathrm{~cm}$. Similar results were also reported by Kumar et al. (2010), Kumar and Kumawat (2014) and Kumar et al. (2018).

Effect of molybdenum on yield and economics: Application of molybdenum significantly influenced the number of branches/plant, number of leaves/plant and seeds/plant of blackgram (Table1). The maximum number of branches/plant (3.30, 5.05 and 5.65 at 40,60 DAS and harvest stage, respectively), number of leaves/ plant $(8.43,14.25$ and 13.9340, 60 DAS and harvest stage, respectively) and seeds/plant (153.30) were recorded under seed treatment with Mo followed by $2 \%$ urea spray twice as compare to control and seed treatment with Molybdenum alone @ $4 \mathrm{~g} / \mathrm{kg}$. Due to presence of adequate amount of major nutrients and availability of Mo in the soil, might have enabled the plant to fix nitrogen from the atmosphere in nodules which improved the plant growth and its development and was probably responsible for increased growth attribute and finally enhanced the yield of blackgram. Similar results have also been reported by Kumaran and Subramanian (2002) in blackgram and Malik et al. (2015) in mungbean.

The highest seed yield ( $810 \mathrm{~kg} / \mathrm{ha})$ and straw yield $(26.98 \mathrm{~kg} / \mathrm{ha}$ ) was recorded in seed treatment with Mo $+2 \%$ urea spray twice, being significant over seed treatment with Mo @ $4 \mathrm{~g} / \mathrm{kg}$ and control (Table 2). The increase in seed yield and biological yield was 15.22 and 5.92 per cent, respectively over control. This might be due to phenomenal increase was attributed apparently to increased availability of nitrogen in the soil which helped the plants to produce abundance of effective nodules which in turn led to produce huge bio-mass, pod and seed yield. These results are contradiction with those obtained by Karpagam and Rajesh (2014) in mungbean and Kumar et al. (2018) in blackgram.

Maximum gross returns (Rs. 33,293/ha) was obtained from the application of seed treatment with molybdenum followed by $2 \%$ urea spray twice 
followed by seed treatment with molybdenum only. Whereas, lowest net return (Rs. 29,089/ha) was recorded in control. Similarly, seed treatment with molybdenum and $2 \%$ urea spray twice gave maximum production efficiency $(9.88 \mathrm{~kg} / \mathrm{ha} /$ day $)$ and economic efficiency (Rs. 226.49/ha/day) which was significantly superior over control and seed treatment alone. The superiority of this treatment combination was might be due to better performance of individual treatments with respect to grain and straw yield production. Kumaran and Subramanian (2002) reported that the treatments as spray 2 per cent DAP +25 ppm ammonium molybdenum $+100 \mathrm{ppm} \mathrm{ZnSO}_{4}+100 \mathrm{ppm} \mathrm{FeSO}_{4}$ +0.5 per cent urea resulted in a higher grain yield. Similar lines of result have also reported by Verma et al. (2011) in greengram and Karpagam and Rajesh (2014) in greengram.

Interaction effect: Seed yield of blackgram was significantly influenced by the interaction effects of row spacings and cultivars (Table 3 ). Indira Urd-1 sown on $30 \times 10 \mathrm{~cm}$ spacing resulted in maximum grain yield $(814.16 \mathrm{~kg} / \mathrm{ha})$. Thus it can be inferred that at the same or different levels of row spacing of $30 \times 10 \mathrm{~cm}$ row spacing maintained its superiority over that of $45 \times 10 \mathrm{~cm}$ spacing. The higher grain yield might be attributed to the higher amount of cumulative solar radiation activating the photosynthesis and favouring accumulation of more synthates in the sink. As regard to cultivars and seed treatment interaction effects data showed that Indira Urd-1 recorded maximum grain yield at all the levels of seed treatments. Significantly highest seed yield of blackgram $(847.09 \mathrm{~kg} /$ ha) was recorded when crop were treated with molybdenum @ $4 \mathrm{~g} / \mathrm{kg}$ seed followed by 2\% urea spray twice and it excelled over all other treatment combinations. In an earlier study also linear increase in seed yield was recorded by Kabir and Sarkar (2008) in mungbean, Rajavel and Vincent (2009) in blackgram and Tahir et al. (2014) in blackgram.

\section{Conclusion}

From the above research findings it may be concluded that cultivars Indira Urd-1 grown with spacing of $30 \times 10 \mathrm{~cm}$ along with seed treatment with Mo @ $4 \mathrm{~g} / \mathrm{kg}+2 \%$ urea spray twice was better for higher seed yield $(781 \mathrm{~kg} / \mathrm{ha})$, and gross returns (Rs. $32,335 / \mathrm{ha})$, production efficiency $(9.52 \mathrm{~kg} / \mathrm{ha} /$ day) and economic efficiency (218.82 Rs./ha/day) of blackgram under rainfed conditions of Chhattisgarh.

\section{REFERENCES}

Joshi, S.K. and Rahevar, H. (2015). Effect of dates of sowing, row spacings and varieties on growth and yield attributes of rabi Indian bean (Dolichos lablab L.). Indian Journal of Agricultural Research, 49 (1): 59-64.

Kabir, M.H. and Sarkar, M.A.R. (2008). Seed yield of mungbean as affected by variety and plant spacing in Kharif-I season. Journal of Bangladesh Agricultural University, 6(2): 239-244.

Karpagam , J. and Rajesh, N. (2014). Molybdenum application for enhancing growth, yield and soil health on green gram (Vigna radiata L.). AmericanEurasian Journal of Agriculture \& Environment Sciences, 14 (12): 1378-1381.

Kumar, A., Singh, S.S., Kumar, R., Kumawat, N. and Singh, A.K. (2010). Response of Rhizobium and different levels of molybdenum on growth, nodulation and yield of blackgram (Vigna mungo L.). Environment and Ecology, 28 (3A):1728-1730.

Kumar, R., Tomar, G.S. and Yadav, R. (2013). Effect of plant density on growth, nodulation and yield of blackgram [Vigna mungo L. Hepper] cultivars. Progressive Research. 8 (2): 325-326.

Kumar, R., Tomar, G.S., Kumawat, N. and Singh, S.P. (2018). Effect of varieties, plant density and molybdenum on yield and economics of blackgram under rainfed condition of Chhattisgarh. International Journal of Chemical Studies, 6(1): 1867-1870.

Kumar, R. and Kumawat, N. (2014). Effect of sowing dates, seed rates and integrated nutrition on productivity, profitability and nutrient uptake of summer mungbean in Eastern Himalaya. Archive of Agronomy and Soil Science, 60 (9): 1207-1227.

Kumar, R., Deka B.C., Kumawat N. and Ngachan S.V. (2014). Effect of integrated nutrition, biofertilizers and zinc on production potential and profitability of garden pea (Pisum sativum L.) in eastern Himalaya, India. Legume Research, 37 (6) : 614-620.

Kumaran, S. and Subramanian, M. (2002). Effect of plant population and methods of nutrient application on yield and economics of blackgram. Research on Crops, 2(3) : 323-326.

Kumawat, N., Singh, R.P., Kumar, R., Yadav, T.P. and Hari, Om. (2015). Effect of integrated nutrient management on productivity, nutrient uptake and economics of rainfed pigeonpea (Cajanus cajan) and blackgram (Vigna mungo) intercropping system. Indian Journal of Agricultural Sciences, 85: 171-176.

Mahilane, C. and Singh, V. (2018). Effect of Zinc and Molybdenum on Growth, Yield Attributes, Yield and Protein in Grain on Summer Blackgram (Vigna mungo L.). International Journal of Current Microbiology and Applied Sciences, 7 (1):1156-1162.

Malik, K., Kumar, S. and Arya, K.P.S. (2015). Effect of zinc, molybdenum and urea on growth and yield of mungbean (Vigna radiata L. Wilczek). Advance $R e-$ search Journal of Crop Improvement, 6 (1): 59-65.

Panotra, N., Kumar, A. and Singh, O.P. (2016). Effect of varieties and dates of sowing on growth parameters, yield attributes and yield of blackgram (Vigna mungo L.). International Journal of Science, Environment and Technology, 5(6): 3821-3826.

Rajavel, M. and Vincet S. (2009). Influence of nutrient and hormones on yield maximization of blackgram. Journal of Ecobiology, 24(4):387-394.

Ranganathan, P. (1990). Statistical analysis of agriculture field experiment, pp, 240-245.

Satyamoorthi, K., Mohamed, A., Somasundaram, E., Pazhanivelan, S. and Vaiyapuri, K. (2008). Root growth and yield of green gram (Vigna radiata (L.) Wilczek) as influenced by increased plant density and nutrient management. Journal of Applied Sciences Research, 4 (7): 917-924. 
Singh, A.K., Singh, S.S., Prakash, V., Kumar, S. and Dwivedi, S.K. (2015). Pulses production in India: present status, bottleneck and way forward. Journal of AgriSearch, 2(2): 75-83.

Singh, G., Sekhon, H.S., Singh, G., Brar, J.S., Bains, T.S. and Shanmugasundaram, S. (2011). Effect of plant density on the growth and yield of mungbean [Vigna radiata (L.) Wilczek] genotypes under different environments in India and Taiwan. International Journal of Agricultural Research, 6 (7): 573-583.

Singh, M., Deokaran, Mishra, J.S. and Bhatt, B.P.
(2017). Effect of integrated nutrient management on production potential and quality of summer mungbean (Vigna radiata L.). Journal of Krishi Vigyan, 5 (2): 39-45.

Tahir, M., Sher, A. and Majeed, A.( 2014). Effect of molybdenum on yield and quality of black gram (Vigna mungo L.). Pakistan Journal of Life and Social Sciences, 12 (2): 101-105.

Verma, C.K., Yadav, D.D. and Singh, V. (2011). Effect on yield and quality of green gram (Vigna radiata L.) varieties by foliar spray of urea and seed rates. Plant Archives, 11 (1): 289-291. 